\title{
MEMÓRIA
}

\section{Memória do Departamento de Filosofia da UFMG}

Iniciamos, neste número, uma seção que pretende ter a função tanto de registro como de homenagem a ex-professores do Departamento de Filosofia da UFMG. Pensamos que é vital para uma instituição pública como a nossa, que pratica a pesquisa e o ensino em Ciências Humanas e Filosofia, cultivar de maneira efetiva sua própria memória. O Departamento existe há cerca de 45 anos e não tem acervos formais ou sistematicamente organizados dos professores e funcionários que nele trabalharam ou de sua produção acadêmica. Esta seção pretende ser um gesto inicial na direção de começarmos a suprir esta lacuna injustificável.

Começamos com a publicação de um artigo da Profa. Léa Ferreira Laterza, texto escrito nos anos 80 e que seria parte da dissertação de Mestrado, que não chegou a concluir.

Marcelo P. Marques

\section{LÉA FERREIRA LATERZA, 1930-2001}

Ricardo Fenati

Léa Ferreira Laterza, bacharel em Filosofia pela Faculdade de Filosofia Ciências e Letras Santa Maria da Universidade Católica de Minas Gerais (1950-1952) e licenciada em Filosofia pela UFMG (1968), foi professora do Departamento de Filosofia desde 1975 até 1992, data de sua aposentadoria. Atuou antes no ensino secundário, em Uberaba e em Belo Horizonte, e na Universidade Federal de Goiás onde, após prestar concurso, foi professora de Estética e Filosofia da Ciência. De volta a Belo Horizonte, lecionou também na Faculdade de Filosofia, Ciências e Letras do Instituto Isabela Hendrix, em 1973/74. 
A partir de janeiro de 1975, passou a integrar o quadro de professores do Departamento de Filosofia, atuando inicialmente no $1^{\circ}$ Ciclo da área de Ciências Sociais, junto à disciplina Lógica do Pensamento Científico. O $1^{\circ}$ Ciclo da área de Ciências Sociais, sediado na Faculdade de Filosofia e Ciências Humanas e inteiramente reformulado a partir de 1975, era formação obrigatória no semestre inicial dos cursos de graduação da FAFICH, à exceção do curso de Psicologia. Agrupando professores, especificamente contratados para aí atuar e fortemente apoiado pela reitoria do Professor Eduardo Osório Cisalpino, o $1^{\circ}$ Ciclo constituiu-se como um espaço de pensamento crítico na universidade, então cerceada pelo governo militar. Tendo como referência as demais disciplinas constantes do currículo - Sociologia, Política e Economia -, a Lógica do Pensamento Científico ocupava-se da epistemologia das ciências sociais, evidenciando a precariedade de todo positivismo e a ingenuidade das correntes que se imaginavam neutras em relação à filosofia.

Foi uma época, meados dos anos 70, em que a filosofia se viu desafiada a ocupar novos espaços na universidade e o fez. Sob a direção do professor José Henrique Santos, o Departamento expandia-se, atuando junto a um grupo crescente de cursos. A professora Léa, permanecendo junto ao $1^{\circ} \mathrm{Ciclo}$, passou a responder, também, pela disciplina Lógica I, no curso de Psicologia. Também aí a filosofia abria um espaço reflexivo importante, dada a onipresença das correntes de inspiração skinneriana, então dominantes no Departamento de Psicologia. Bem sucedida, a experiência deu lugar a outra disciplina, Lógica II, onde as questões de fundamento eram ampliadas e mais detalhadamente discutidas, o que, com o tempo, possibilitou, junto com outros fatores, a que outras abordagens viessem a fazer parte da formação discente na psicologia. Nas duas disciplinas, a atuação continuada da professora Léa caracterizou-se seja pela competência, seja pela propriedade da análise filosófica.

Um pouco mais tarde, com os espaços de atuação no $1^{\circ}$ Ciclo e no Departamento de Psicologia já consolidados, a professora Lea passou a lecionar História da Filosofia Medieval, no curso de graduação em Filosofia. Então prima pobre da filosofia grega, a filosofia medieval, não raro, era vista como um território sem maior importância, mera passagem da Antiguidade para a Filosofia Moderna. A professora Léa, primeira professora com atuação contínua na disciplina, contribuiu, em muito, para a revisão desta imagem distorcida do pensamento medieval. O seu trabalho, ao longo dos anos, evidenciou a propriedade da tese de que a proximidade com a teologia cristã não impede a existência de um espaço típica e legitimamente filosófico no pensamento medieval. 
A professora Léa, na diversidade dos cursos de que se ocupou, em muito contribuiu para a solidificação da imagem da filosofia junto à Universidade, etapa propiciadora e necessária à projeção nacional e internacional com que hoje conta o Departamento. Ao longo dos anos, integrou o acervo de bons professores, traço identificador do Departamento de Filosofia.

À sua atuação como docente, a professora Léa somou extensa atividade administrativa junto aos órgãos colegiados e, quando da transferência da FAFICH para o Campus da Pampulha, foi coordenadora do curso de graduação em Filosofia.

Entretanto, estas notas que assinalam, de modo rápido e resumido, o percurso profissional da professora Léa Ferreira Laterza apenas deixam entrever o seu profundo compromisso com a educação e a capacidade, que tanto a singularizava, de fazer da sala de aula e de sua prática docente uma lição constante de defesa do ideal de um humanismo generoso e inclusivo. Sua biblioteca sempre esteve aberta a todos os que dela necessitavam e ali encontrávamos os livros, e não foram poucos, ainda inexistentes na biblioteca do Departamento. Suas aulas prolongavam-se para além dos muros da escola e muitos dos seus alunos ali continuavam a aprender, prosseguindo as discussões a que as aulas davam início. Agora, além de alunos, amigos. A partir dos anos 70, na sua casa, na rua Cláudio Manoel e depois na rua Dante, na Serra e no são Lucas, muitos de nós, os seus colegas professores, tínhamos uma espécie de segunda casa. O que, aliás, era uma tradição, já que nos anos 60, em meio à ditadura que também a fez sofrer, sua casa esteve aberta intelectual e existencialmente a toda uma geração. Seu cristianismo foi sempre um instrumento de aproximação da vida na variedade de suas dimensões.

Foi um outro tempo, é certo, com seus traços e suas questões, mas sob o que há de mutável e passageiro na história, a trajetória da professora Léa Ferreira Laterza reuniu o que nos torna em qualquer tempo, mais do que professores, educadores: a competência intelectual, a sensibilidade diante das questões humanas e a coragem diante da existência. Penso que ela gostaria de ser lembrada como quem combateu o bom combate. E é assim que nós nos lembramos da professora Léa Ferreira Laterza. 